\title{
Heart failure, oxidative stress and allopurinol
}

\section{Scompenso cardiaco e stress ossidativo: ruolo dell'allopurinolo}

\author{
Paolo Biagi, Luigi Abate
}

\begin{abstract}
Heart failure, oxidative stress and allopurinol. P. Biagi, L. Abate.

Oxidative stress is one of the new and most intriguing pathogenetic hypotheses of heart failure; it involves various mechanisms such as endothelial dysfunction, mechanoenergetic uncoupling and apoptosis.

Xanthine oxidase, a key enzyme in purine catabolism, is overexpressed in patients with heart failure, and it is also an important source of oxidizing activity molecules (free radicals, superoxide anion, oxygen peroxide, etc...). Allopurinol competitively inhibits the action of xanthine oxidase and effectively coun-
\end{abstract}

ters oxidative stress. It could thus prove useful in the treatment of heart failure: in fact it is the only drug that has been proven able to lower $\mathrm{O}_{2}$ consumption of dysfunctioning myocardium.

The Authors briefly review the xanthine oxido-reductase enzyme system and in particular analyse the latest evidence reported in the literature on allopurinol in the treatment of heart failure.

Keywords: heart failure, uric acid, oxidative stress, allopurinol.

Monaldi Arch Chest Dis 2005; 64: 33-37.

Unità Funzionale di Medicina Interna (Direttore dott. Paolo Biagi); Ospedali Riuniti della Val di Chiana Senese; 53045 Montepulciano (Siena); ASL 7 - Siena.

Corresponding author: Dr Paolo Biagi; UF Medicina Interna; Ospedali Riuniti della Val di Chiana Senese; Via di Gracciano I-53045 Montepulciano (Siena), Italy; e-mail: chipama@libero.it; Dr Luigi Abate; E-mail address: villabercio@tiscali.it

The burden of heart failure (HF) is increasing rapidly, on account of the aging population and the improving survival of patients with other heart diseases, most resulting in HF. It is further reflected in the associated mortality figures (first year mortality rates $25-35 \%$ ) and substantial morbidity. The shortterm intravenous acute HF treatment with inotropic agents such as dobutamine, amrinone effectively alleviate HF symptoms, but their use is limited by concerns about safety, particularly ventricular arrhythmias. ${ }^{1}$ Nesiritide (recombinant B-type natriuretic peptide, or BNP) is more effective than i.v. nitroglycerine in reducing pulmonary arterial pressure and pulmonary capillary wedge pressure, but clinically significant hypotension in some patients restricts its use and it is not yet licensed in Italy. ${ }^{2}$

To date, the current standard care for chronic oral HF therapy includes the administration of an angiotensin converting enzyme (ACE) inhibitor (or ATII antagonist), a diuretic (furosemide), a betablocker, a vasodilator, and possibly digoxin.

However, many patients remain symptomatic despite full therapy, and mortality continues to be significant, thus underlining the need for new therapeutic options.

Among the pathogenetic factors involved in HF recent theories include oxidative stress, which through the production of reactive oxygen species (ROS), 3-5 induces apoptosis, 6 endothelial dysfunction, 7 and myocardial remodelling. 8

Moreover in CHF, a phenomenon known as mechano-energetic uncoupling, that is an imbalance between left ventricular performance and myocardial oxygen consumption $\left(\mathrm{MVO}_{2}\right)$, leads to a decrease in cardiac contractile efficiency. ${ }^{9}$
Although there are many possible sources of ROS production, it has been shown that the enzyme xanthine oxidase $(\mathrm{XO})$, undergoes overexpression at the endothelial level in such conditions as ischemiareperfusion ${ }^{10}$ and heart failure 11 and it is able to induce oxidative stress. Therefore we investigated the role of $\mathrm{XO}$ in the mechanisms of heart failure and analysed the potential of allopurinol, a XO inhibitor, in the treatment of heart failure.

\section{The pathophysiological role of xantino oxido-reductase}

Xantino oxido-reductase (XOR), one of the molybdenum enzyme family, 12 was discovered 100 years ago 13 in human milk where it participate in antiseptic mechanisms, perhaps via a NO-dependent action, recently identified in vitro:14 in fact in newborn breastfed infants (whose mothers milk is rich in XOR), episodes of gastroenteritis are less frequent than in infants fed with artificial milk. 15

In man, XOR is not particularly abundant. 16 However, relatively high concentrations may be found in the endothelial cells of capillaries and sinusoids. The gene controlling its synthesis is located in the short arm of chromosome 2.17 Some cytochines, such as TNF-alpha, IFN-gamma, IL-1, IL-6, or treatment with desametasone, enhance its transcription in vitro. 18

The gene expression of XOR in the endothelial cell is also dependent on partial tension of $\mathrm{O}_{2}$ : in fact in the ischemia-reperfusion phenomenon XOR overexpression in the ischemic limb is mediated through enhanced XOR transcription induced by hypoxia; on the contrary hyperoxia switches off transcription. 19 
Actually the most important function is associated with the catabolism of purines. ${ }^{20}$ In the enzymatic steps to the end product (uric acid) XOR generates free radicals: in fact, XOR is converted by two reversible pathways which involve xanthine-dehydrogenase $(\mathrm{XDH})$ and $\mathrm{XO}$ respectively: the first produces uric acid and NADH, the second uric acid, free radicals and superoxide anion ${ }^{21}$ (figure 1).

In addition, as an alternative source of NO production, XOR seems to contribute to endothelial-dependent vasodilatation when the activity of NO-synthase is not functioning as, for example, in the case of hypoxia. 22 This phenomenon has been reproduced experimentally in rats, in which production of $\mathrm{NO}$ has been demonstrated in conditions of heart hypoxia and of inhibition of NO-synthase, but not if $\mathrm{XO}$ is blocked by pre-treatment with allopurinol.23

The activity of XO may increase the following vascular damage caused by ischemia-reperfusion, anoxia and inflammation 24 , probably due to the lesion of the endothelial lining. Alternatively, interacting with non-ferritinic endocellular iron, through the conversion of the dehydrogenated form into the oxidated form, it may produce an excess of free radicals including hydrogen peroxide which is proven to be the most important for $\mathrm{XO}$-induced endothelial damage. 25

In addition, superoxide radicals $\left(\mathrm{O}_{2}^{-}\right)$produced by $\mathrm{XO}$ react with $\mathrm{NO}$ forming peroxynitrite $\left(\mathrm{ONOO}^{-}\right)$, a powerful oxidyzing agent, which causes the deactivation of $\mathrm{NO}$ and contributes to endothelial damage. 26

In a small randomized trial the endoarterial administration of allopurinol, a competitive inhibitor of XO, improved endothelial dysfunction measured according to the model of venous forearm occlusion. This effect was also obtained by oral administration of allopurinol 27 and confirmed by a randomized controlled double blind trial in $\mathrm{CHF}$ patients on optimized treatment (diuretics, ACEinhibitors, beta-blockers): 28 chronic oral treatment with allopurinol (300 mg/die) improved endothelial dysfunction.

\section{Oxidative stress, heart failure and allopurinol}

In heart failure the activity of XOR at cardiac and endothelial level is overexpressed, whilst the activity of superoxide dismutase (SOD) neutralizing the oxiding effect of $\mathrm{O}_{2}$ is significantly reduced.29

This imbalance enhances the production of ROS with the resulting reduction of $\mathrm{NO}$ bioavaibility and increases the levels of peroxynitrite derived from the reaction between $\mathrm{NO}$ and superoxide 30 (figure 2).

Heart dysfunction, initially characterized by impairment in heart contraction and then by hypertrophy and remodelling, is probably more the consequence of endothelial dysfunction ${ }^{31}$ than ROS-induced modulation of fibroblast proliferation and collagen synthesis. 32 Alternatively the superoxide may interfere with intracellular key regulators of the energy metabolism such as ATP,33 high energy phosphate $^{34}$ and calcium, inducing mechano-energetic uncoupling. This means that in HF in the presence of reduced ventricular

Figure 1. - Conversion of xanthine oxido-reductase into xanthine dehydrogenase and xanthine oxidase.

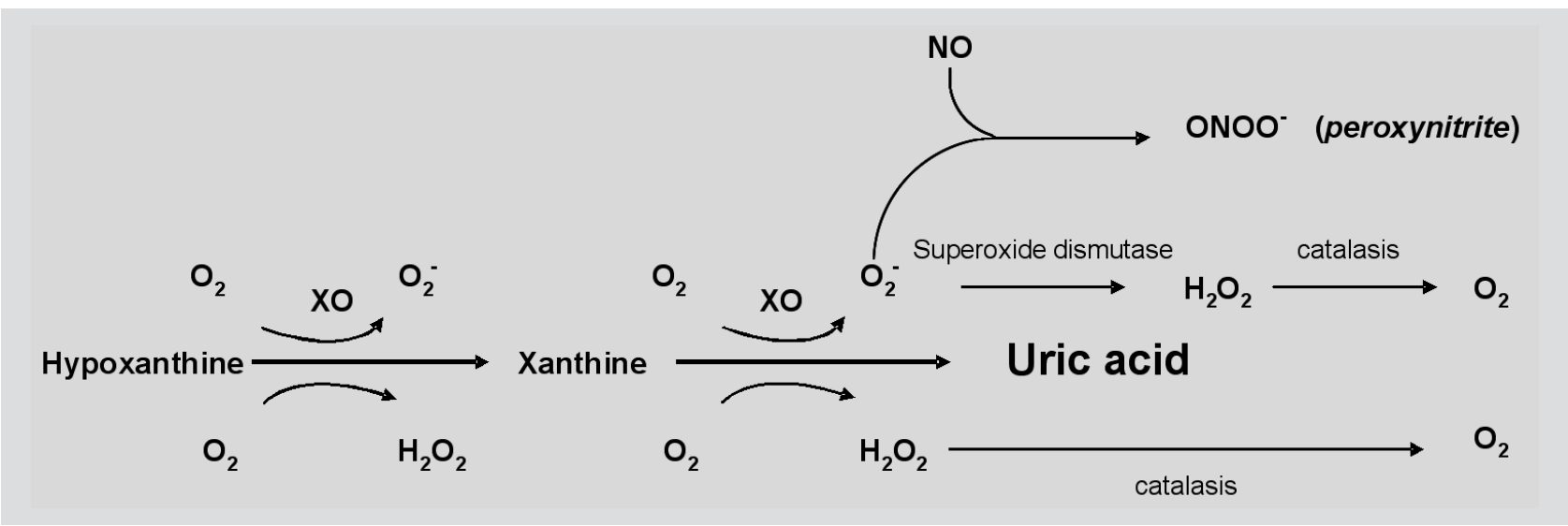

Figure 2. - Conversion of xanthine oxido-reductase into xanthine dehydrogenase and xanthine oxidase (Modified from Elion GB 35 ). 
function the energy cost (i.e. the consumption of $\mathrm{O}_{2}$ ) of contraction remains unchanged.

Allopurinol is an analogous of hypoxanthine and acts via competitive inhibition of XO, as well as by reducing the absorption of diet purines.

The inhibition of XO prevents the transformation of hypoxanthine into xanthine and thence into uric acid; to avoid the storage and hence increased excretion of xanthine and hypoxanthine, two metabolic processes are involved in the regulation of the biosynthesis of purines, 35 namely:

- the first process, the "hypoxanthine saving pathway", enables the hypoxanthine to be used again to produce nucleic acid; this process is supervised by the phosporibosil-transferase hypoxanthine-guanine enzyme (HGPRtase);

- the second process inhibits the first stage of the synthesis of purines (guanilic acid -GMP- and adenilic acid -AMP- formation) blocking the phosphoribosil-pyrophosphate aminotransferase enzyme.

Allopurinol has been shown to increase cardiac efficiency in animal models of pacing-induced heart failure 36 and to enhance the contractile response of the failing myocardium to dobutamine and to exercise. ${ }^{37}$ The increase in contractility without a disproportionate increase in $\mathrm{MVO}_{2}$ is achieved by an increased sensitization of the cardiac myofilaments to calcium. ${ }^{38}$ This evidence in animals has been confirmed also in man where recently XOR activity has been found in the cardiac muscle. 39

The infusion of allopurinol in the coronary arteries of patients with dilated cardiomyopathy, led to improved ventricular contraction supported by reduced $\mathrm{O}_{2}$ consumption. 40 In addition, several randomized placebo-controlled clinical trials have shown allopurinol to improve cardiac performance and reduce the need for inotropic supportive therapy in patients undergoing cardiac surgery. 41,42

In a clinical study in nine HF patients allopurinol improved cardiac pressure efficiency by $22 \%$ and cardiac mechanical efficiency by $40 \% .40$

A recent cohort retrospective study of more than 1700 patients suffering from HF, divided into no treatment, low and high doses of allopurinol groups, showed that chronic treatment with high doses of allopurinol ( $\geq 300 \mathrm{mg} / \mathrm{die}$ ) was significantly related to lower total mortality, cardiovascular mortality, and hospitalization rate for cardiovascular disease (primary and combined end points). 43

Most probably effects of allopurinol are mediated by its conversion in the active metabolite oxipurinol, a powerful XO inhibitor and an orphan drug, available in USA since 1967 for patients intollerant to allopurinol.

Recent pilot studies concluded in 2004 show that oxipurinol may be useful as an acute intravenous and oral therapy in CHF: interim results of LaPlata Study and EXOTIC-EF (Evaluation of Xanthine Oxidase InhibiTion on Cardiac Ejection Fraction) were presented at the Heart Failure Society of America's annual meeting recently held in Toronto. Both studies showed a significant improvement of cardiac function as measured by the left ventricle ejection fraction (LVEF). The LaPlata Study, a blinded, placebo-controlled study showed an improvement of $3.3 \%(\mathrm{p}<0.010)$ in LVEF vs. placebo
28 days after oral oxipurinol ( $600 \mathrm{mg} / \mathrm{die})$. The EXOTIC-EF open-label study showed a $3.6 \%$ (p $<0.0032$ ) increase in LVEF after i.v. treatment with oxipurinol $400 \mathrm{mg} / \mathrm{die}$.

The OPT-CHF study, an ongoing phase II-III prospective, randomized, double-blind, placebo-controlled trial, including 400 pts with stable NYHA class III and IV congestive HF, will test the benefit of oxipurinol $600 \mathrm{mg} /$ die added to the standard optimized therapy on 6 months clinical outcomes. The end of the study is foreseen in the second half of $2005 .{ }^{44}$

\section{Conclusion}

Although conclusive evidence is still lacking on the real burden of oxidative stress in heart failure and taking into account that no benefit of other anti-oxidative drugs (ascorbic acid, vitamin $\mathrm{E}$ etc...) has been proved, some data show that reducing the level of $\mathrm{O}_{2}$ free radical may be useful in the management of HF.

In this setting AP could be an effective and inexpensive way of controlling oxidative stress and hence of improving endothelial dysfunction; moreover XO inhibitors are the first to be shown to reduce mechano-energetic uncoupling in the failing heart. 45

Obviously larger randomized and controlled trials are required to validate these preliminary results and to test the risk-benefit ratio for allopurinol sideeffects not to be forgotten; a wider use of oxipurinol, a safer alternative to allopurinol intolerant patients, by i.v. or oral route may offer another therapeutic option: the results of the ongoing trials will be soon available.

At present, despite the fact that the treatment is not recommended in HF guidelines, it is common practice to prescribe allopurinol in addition to optimized therapy to control hyperuricemia induced by diuretics: in such a way we may join the "symptomatic" to an extended "pathogenetic" effect of allopurinol.

\section{Riassunto}

Tra le più interessanti ipotesi patogenetiche recentemente postulate riguardo allo scompenso cardiaco una concerne lo stress ossidativo che sembrerebbe condurre mediante l'attivazione di molteplici meccanismi (disfunzione endoteliale, disaccoppiamento meccano-energetico, apoptosi, etc...) alla disfunzione miocardica.

La xantina-ossidasi, enzima chiave nel catabolismo delle purine, oltre che essere sovraespressa in condizioni di scompenso cardiaco, è anche una notevole fonte di produzione di molecole ad azione ossidante e è quindi potenzialmente implicata nella sua genesi. L'allopurinolo, un inibitore competitivo della xantina ossidasi, è pertanto in grado di contrastare lo stress ossidativo: in tal senso potrebbe costituire un farmaco utile nel trattamento della disfunzione ventricolare anche perché si è dimostrato essere l' unico in grado di ridurre, a parità di carico di lavoro, il consumo di $\mathrm{O}_{2}$ da parte del miocardio.

Gli Autori, dopo aver preso in esame il complesso delle funzioni del sistema enzimatico della 
xantina ossido-reduttasi, analizzano le più recenti evidenze riportate in letteratura sull' impiego dell'allopurinolo nello scompenso cardiaco.

Parole chiave: scompenso cardiaco, acido urico, stress ossidativo, allopurinolo.

\section{LIST OF ABBREVIATIONS OR ACRONYMS}

ACE-inhibitor: Angiotensin Converting Enzyme inhibitor AMP: Adenilic acid

AO: Aldehyde oxidase

ATP: Adenosine triphosphate

BNP: Brain natriuretic peptide

GMP: Guanilic acid

HF: Heart failure (according to Framingham criteria)

HGPRtasi: Phosphoribosil pyrophosphate aminotransferase

IFN gamma: Interferon gamma

IL-1: Interleukin-1

IL-6: Interleukin-6

$\mathrm{MVO}_{2}$ : Myocardial oxigen consumption

NO: Nitric oxide

$\mathrm{O}_{2}$ : Molecular oxygen

$\mathrm{O}_{2}^{-}$: Superoxide anion

ONOO-: Peroxynitrite

SO: Sulphate oxidase

SOD: Superoxide dismutase

TNF- $\alpha$ : Tumor necrosis factor alpha

$\mathrm{XDH}$ : Xanthine dehydrogenase

XO: Xanthine oxidase

XOR: Xanthine oxido-reductase

\section{References}

1. Manito N, Kaplinsky EJ, Pujol R. Inotropic therapy in heart failure: general aspects and clinical results. Med Clin (Barc) 2004; 122: 269-274.

2. Michaels AD, Klein A, Madden JA, et al. Effects of intravenous nesiritide on human coronary vasomotor regulation and myocardial oxygen uptake. Circulation 2003; 107: 2697-2701.

3. Byrne JA, Grieve DJ, Cave AC et al. Oxidative stress and heart failure. Arch Mal Coeur 2003; 96: 214-221.

4. Keith M, Geranmayegan A, Sole MJ, et al. Increased oxidative stress in patients with congestive heart failure. $J$ Am Coll Cardiol 1998; 31: 1352-1356.

5. Belch JJ, Bridges AB, Scott N, et al. Oxygen free radicals and congestive heart failure. Br Heart J 1991; 65: 245-248.

6. Von Harsdorf R, Li PF, Dietz R. Signaling pathways in reactive oxygen species-induced cardiomyocyte apoptosis. Circulation 1999; 99: 2934-2941.

7. Bauersachs J, Bouloumie A, Fraccarollo D, et al. Endothelial dysfunction in chronic myocardial infarction despite increased vascular endothelial nitric oxide synthase and soluble guanylate cyclase expression: role of enhanced vascular superoxide production. Circulation 1999; 100: 292-298.

8. Kinugawa S, Tsutsui H, Hayashidani S, et al. Treatment with dimethylthiourea prevents left ventricular remodeling and failure after experimental myocardial infarction in mice: Role of oxidative stress. Circ Res 2000; 87: 392-398.

9. Saavedra WF, Paolocci N, St John ME, et al. Imbalance between xanthine oxidase and nitric oxide synthase signaling pathways underlies mechanoenergetic uncoupling in the failing heart. Circ Res 2002; 90: 297-304.

10. Brown JM, Terada LS, Grosso MA, et al. Xanthine oxidase produces hydrogen peroxide which contributes to reperfusion injury of ischemic, isolated, perfused rat hearts. J Clin Invest 1988; 81: 1297-1301.
11. De Jong JW, Schoemaker RG, de Jonge R, et al. Enhanced expression and activity of xanthine oxido-reductase in the failing heart. J Mol Cell Cardiol 2000; 32: 2083-2089.

12. Kisker C, Schindelin H, Rees DC. Molybdenum-cofactor-containing enzymes: structure and mechanism. Ann Rev Biochem 1997; 66: 233-267.

13. Schardinger F. Uber das verhalten der kuhmilch gegen methylenblau und seine verwendung zur unterscheidung von ungekochter und gekochter milch. Untersuch Nahrungs Genussmittel 1902; 5: 1113-1121.

14. Hancock JT, Salisbury V, Ovejero-Boglione MC, et al. Antimicrobial properties of milk: dependance on presence of xanthine oxidase and nitrite. Antimicrob Agents Chemother 2002; 46: 3308-3310.

15. Stevens CR, Millar TM, Clinch JG, et al. Antibacterial properties of xanthine oxidase in human milk. Lancet 2000; 356: 829-830.

16. Linder N, Rapola J, Raivio KO. Cellular expression of xanthine oxido-reductase protein in normal human tissues. Laboratory Invest 1999; 79: 967-974.

17. Xu P, Zhu XL, Huecksteadt T, et al. Assignment of human xanthine dehydrogenase gene to chromosome $2 \mathrm{p} 22$. Genomics 1994; 23: 289-291.

18. Pfeffer K, Huecksteadt T, Hoidal JR. Xanthine dehydrogenase and xanthine oxidase activity and gene expression in renal epithelial cells: cytokine and steroid regulation. $J$ Immunol 1994; 153: 1789-1797.

19. Hassoun PM, Yu F, Cote CG, et al. Upregulation of xanthine oxidase by lipopolysaccharide, interleukin-1, and hypoxia: role in acute lung injury. Am J Resp Crit Care Med 1998; 158: 299-305.

20. Aldermann M, Aiyer KJV. Uric acid: role in cardiovascular disease and effects of losartan. Curr Med Research and Opinions 2004; 20 (3): 369-379.

21. Enroth C, Eger BT, Okamoto K, et al. Crystal structures of bovine milk xanthine dehydrogenase and xanthine oxidase: structure based mechanism of conversion. Proc Natl Acad Sci USA 2000; 97: 10723-10728.

22. Millar TM, Stevens CR, Benjamin N, et al. Xanthine oxido-reductase catalises the reduction of nitrates and nitrite to nitric oxide under hypoxic conditions. FEBS Lett. 1998; 427: 225-228.

23. Li H, Samouilov A, Liu X, et al. Characterization of the magnitude and kinetics of xanthine oxidase catalyzed nitrate reduction: evaluation of its role in nitrite and nitric oxide generation in anoxic tissue. Biochemistry 2003; 42; 1150-1159.

24. Poss WB, Huecksteadt TP, Panus PC, et al. Regulation of xanthine dehydrogenase and xanthine oxidase activity by hypoxia. Am J Physiol 1996; 270: L941-L946.

25. Kvietys PR, Inauen W, Bacon BR, et al. Xanthine oxidase-induced injury to endothelium: role of intracellular iron and hydroxyl radical. Am J Physiol 1989; 257: H1640-H1646.

26. Godber BLJ, Doel JJ, Durgan J, et al. A new route to peroxynitrite: a role for xanthine oxido-reductase. FEBS Lett 2000; 475: 93-96.

27. Doehner W, Schiene N, Rachhaus M, et al. Effects of xanthine oxidase inhibition with allopurinol on endothelial function and peripheral blood flow in hyperuricemic patients with chronic heart failure: results from 2 placebo controlled studies. Circulation 2002; 105: 2619-2624.

28. Farquhason CAJ, Butler R, Hill A, et al. Allopurinol improves endothelial dysfunction in chronic heart failure. Circulation 2002; 106: 221-226.

29. Landmesser U, Spiekermann S, Dikalov S, et al. Vascular oxidative stress and endothelial dysfunction in patients with chronic heart failure: role of xanthine oxidase and extracellular superoxide dismutase. Circulation 2002; 106: 3073- 3078 .

30. Wang C, Deen W. Peroxynitrite delivery methods for toxicity studies. Chem Res Toxicol 2004; 17: 32-44.

31. Katz SD, Hryniewicz K, Hriljac I, et al. Vascular en- 
dothelial dysfunction and mortality risk in patients with chronic heart failure. Circulation 2005; 111: 310-314.

32. Spinale FG. Matrix metalloproteinases: regulation and dysregulation in the failing heart. Cir Res 2002; 90: 520-530.

33. Shen W, Wolin MS, Hintze TH. Detective endogenous nitric oxide mediated modulation of cellular respiration in canine skeletal muscle after the development of heart failure. J Heart Lung Transplant 1997; 16: 1026-1034.

34. Campbell DL, Stamler JS, Strass HC. Redox modulation of L-type calcium channel in ventricular myocites: dual mechanism regulation by nitric oxide and S-nitrosothiols. J Geno Physiol 1996; 108: 277-293.

35. Elion GB. Allopurinol and other inhibitors of urate synthesis. In Kelley VN, Weiner IM (eds): "Uric acid" Berlin, Springer Verlag, 1978; 51: 485-514.

36. Ekelund UEG, Harrison RW, Shokek O, et al. Intravenous allopurinol decreases myocardial oxygen consumption and increases mechanical efficiency in dogs with pacing induced heart failure. Circ Res 1999; 85: 437-445.

37. Ukai T, Cheng C, Tachibana H, et al. Allopurinol enhances the contractile response to dobutamine and exercise in dogs with pacing induced heart failure. Circulation 2001; 103: 750-755.

38. Perez NG, Gao WD, Marban E. Novel myofilament $\mathrm{Ca} 2^{+}$-sensitizing property of xanthine oxidase inhibitors. Circ Res 1998; 83: 423-430.
39. Vickers S, Schiller HJ, Hildreth JEK, et al. Immunoaffinity localization of the enzyme xanthine oxidase on the outside surface of endothelial cell plasma membrane. Surgery 1998; 124; 551-560.

40. Cappola TP, Kass DA, Nelson GS et al. Allopurinol improves myocardial efficiency in patients with idiopathic dilated cardiomyopathy. Circulation 2001; 104: 2407-2411.

41. Johnson WD, Kayser KL, Brenowitz JB, et al. A randomized controlled trial of allopurinol in coronary bypass surgery. Am Heart J 1991; 121: 20-4.

42. Castelli P, Condemi AM, Brambillasca C, et al. Improvement of cardiac function by allopurinol in patients undergoing cardiac surgery. J Cardiovasc Pharmacol 1995; 25: 119-125.

43. Struthers AD, Donnan PT, Lindsay P, et al. Effect of allopurinol on mortality and hospitalisations in chronic heart failure: a retrospective cohort study. Heart 2002, 87: 229-234.

44. Freudenberger RS, Schwarz RP, Brown J et al. Rationale, design and organisation of an efficacy and safety study of oxypurinol added to standard therapy in patients with NYHA class III - IV congestive heart failure. Expert Opin Investig Drugs 2004; 13: 1509-1516.

45. Landmesser U, Drexler H. Allopurinol and endothelial function in heart failure: future or fantasy? Circulation 2002; 106: 173-175.

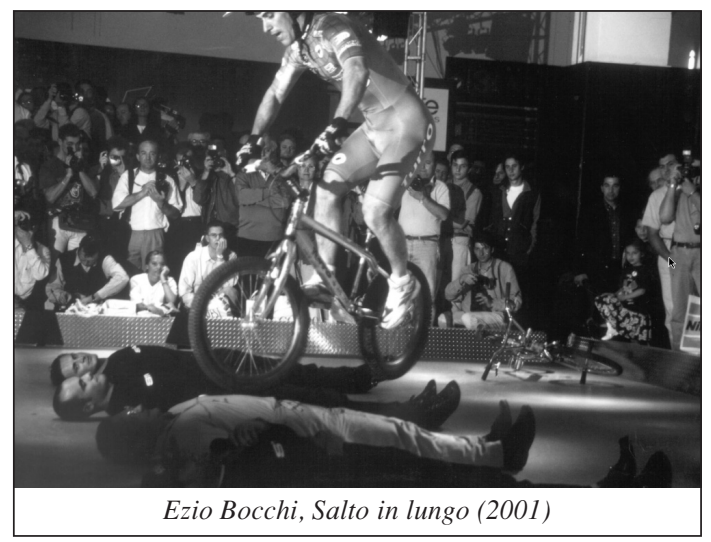

